\title{
KONTRIBUSI GAYA KEPEMIMPINAN KEPALA SEKOLAH, KOMITMEN ORGANISASI, IKLIM KERJA DAN MOTIVASI KERJA TERHADAP KINERJA GURU SMP NEGERI 2 SINGARAJA
}

\author{
Nyoman Ayu Ratmini ${ }^{1}$, I Nyoman Natajaya ${ }^{2}$, I Gusti Ketut Arya Sunu ${ }^{3}$ \\ Program Studi Administrasi Pendidikan, Program Pascasarjana \\ Universitas Pendidikan Ganesha \\ Singaraja, Indonesia \\ ayu.ratmini, nyoman.natajaya, arya.sunu\}@pasca.undiksha.ac.id
}

\begin{abstract}
Abstrak
Penelitian ini bertujuan untuk mengetahui besarnya kontribusi gaya kepemimpinan kepala sekolah, komitmen organisasi, iklim kerja, dan motivasi kerja terhadap kinerja guru SMP Negeri 2 Singaraja. Penelitian "ex-post facto" ini melibatkan 60 guru SMP Negeri 2 Singaraja sebagai subjek penelitian. Data dikumpulkan dengan kuesioner serta dianalisis dengan analisis regresi sederhana, teknik deskriptif statistik, regresi berganda dan korelasi parsial. Hasil penelitian menunjukkan bahwa terdapat kontribusi yang signifikan antara: (1) gaya kepemimpinan kepala sekolah terhadap kinerja guru dengan sumbangan efektif sebesar $25,43 \%$, (2) komitmen organisasi terhadap kinerja guru dengan sumbangan efektif sebesar 20,02\%, (3) iklim kerja terhadap kinerja guru dengan sumbangan efektif sebesar $20,87 \%$, (4) motivasi kerja terhadap kinerja guru dengan sumbangan efektif sebesar $15,97 \%$, (5) secara simultan, terdapat kontribusi yang signifikan antara gaya kepemimpinan kepala sekolah, komitmen organisasi, iklim kerja, dan motivasi kerja terhadap kinerja guru dengan kontribusi sebesar 82,29\% terhadap kinerja guru SMP Negeri 2 Singaraja.
\end{abstract}

Kata kunci: gaya kepemimpinan, komitmen organisasi, iklim kerja, motivasi kerja, kinerja guru

\begin{abstract}
This study aimed at finding out the contribution of principal leadership style, organizational commitment, work climate and work motivation to teacher performance at SMP Negeri 2 Singaraja. This study was an ex post facto research with the population of all teachers at SMP Negeri 2 Singaraja with the total number of 60 persons. The data were collected with questionnaire. The data were analyzed with descriptive statistical technique, simple regression, multiple regression and partial correlation. The result showed that (1) there was a significant contribution of the principal leadership style to teacher performance with effective contribution of $25.43 \%$; (2) there was a significant contribution of organizational commitment to teacher performance with effective contribution of $20.02 \%$; (3) there was a significant contribution of work climate to teacher performance with effective contribution of $20.87 \%$; (4) there was a significant contribution of work motivation to teacher performance with effective contribution of $15.97 \%$ and (5) simultaneously, there was a significant contribution of principal leadership style, organizational commitment, work climate and work motivation to teacher performance of $82.29 \%$.
\end{abstract}

Keywords: leadership style, organizational commitment, work climate, work motivation, teacher performance. 


\section{PENDAHULUAN}

Pendidikan adalah salah satu institusi yang berperan menyiapkan sumber daya manusia. Sejalan dengan perkembangan zaman, tantangan yang dihadapi sistem pendidikan semakin meningkat, baik kualitas, kuantitas maupun relevansinya. Pekembangan masyarakat yang diikuti dengan perkembangan kebutuhannya memunculkan jenis dan bentuk pekerjaan baru yang memerlukan penyesuaian sensifikasi kemampuan dan persyaratan dari tenaga kerjanya. As'ari (2008: 1-2). Arus globalisasi menimbulkan tantangan daya saing terhadap produk sumber daya dan jasa. Sistem pendidikan yang bermutu akan mampu meningkatkan kualitas sumber daya manusia.

Pembangunan sumber daya manusia melalui pendidikan sekolah, merupakan tantangan yang harus dihadapi oleh setiap insan pendidikan terutama guru, yang merupakan garda terdepan dalam dunia pendidikan formal. Guru secara fungsional tugas utamanya adalah memberikan layanan teknis kependidikan kepada peserta didik. Guru dianggap sebagai pihak yang bertanggung jawab dalam oprasional pendidikan di tingkat sekolah formal, sehingga ketika pendidikan dituding sebagai penyebab turunnya kualitas sumber daya manusia, maka secara langsung guru dianggap sebagai pihak yang paling bertanggung jawab. Pada sekolah yang mempunyai visi untuk menghasilkan tenaga atau sumber daya manusia yang siap mendukung pembangunan nasional, terutama dalam mengantisipasi lptek yang begitu pesat, semua itu tidak terlepas dari peranan guru sebagai salah satu komponen sekolah formal. Yang pada akhirnya kualitas sumber daya manusia dan jasa menjadi meningkat, sehingga diharapkan mampu menjadi tuan rumah dinegerinya sendiri dan dapat bersaing dipasar global.

Semua komponen lain, mulai dari kurikulum, sarana-prasarana, biaya dan sebagainya tidak akan banyak berarti apabila keutamaan pembelajaran yaitu interaksi guru dengan peserta didik tidak berkualitas. Semua komponen lain, terutama kurikulum akan "hidup" apabila dilaksanakan oleh guru. Peranan guru sangat penting dalam mentransformasikan input pendidikan, sehingga dapat dipastikan bahwa disekolah tidak akan ada perubahan atau peningkatan kualitas tanpa adanya perubahan dan peningkatan kualitas guru. Hai ini berarti, pendidikan yang baik dan unggul tetap akan bergantung pada kondisi mutu guru. UNESCO menyatakan bahwa "memperbaiki mutu pendidikan pertamatama tergantung pada perbaikan perekrutan, pelatihan, status sosial dan kondisi para guru, mereka membutuhkan pengetahuan dan keterampilan, karakter personal, prospek profesional dan motivasi yang tepat jika ingin memenuhi harapan stakeholder.

Kinerja guru yang diharapkan dapat mendongkrak kualitas dan relevansi pendidikan, dalam implementasinya dilapangan tergantung dari banyak faktor yang mempengaruhinya dan saling berkaitan, misalnya faktor gaya kepemimpinan kepala sekolah, komitmen organisasi, iklim kerja, motivasi kerja guru dan kinerja guru.

Kinerja adalah perilaku nyata yang ditampilkan setiap orang sebagai prestasi kerja sesuai dengan peranannya. Kinerja merupakan suatu wujud perilaku seseorang atau organisasi dengan orientasi prestasi. Kinerja guru dapat dilihat dan diukur berdasarkan spesifikasi kompetensi yang harus dimilikinya. Indikator penilaian terhadap kinerja guru dilakukan terhadap tiga kegiatan pembelajaran dikelas yaitu, perencanaan kegiatan pembelajaran, kegiatan pembelajaran dan evaluasi pembelajaran.

Berdasarkan pendapat diatas, komitmen guru merupakan kekuatan bathin yang datang dari dalam hati seorang guru dan kekuatan dari luar itu sendiri tentang tugasnya yang dapat memberi pengaruh besar terhadap sikap guru berupa tanggung jawab dan responsive dan inovatif terhadap perkembangan ilmu pengetahuan dan tekhnologi.

Dari uraian tersebut dapat diartikan bahwa komitmen guru yang profesional adalah suatu keterikatan diri terhadap tugas dan kewajiban sebagai seorang guru, yang dapat melahirkan tanggung jawab dan sikap responsive dan inovatif terhadap perkembangan ilmu pengetahuan dan teknologi.

Sebagai titik awal pengembangan kerangka konseptual yaitu keberadaan guru sebagai salah satu unsur di lembaga pendidikan sangatlah penting artinya bagi sekolah formal. Dalam perkembangannya sekolah akan menghadapi masalah tenaga kerja/guru 
yang semakin kompleks, dengan demikian pengelola sumber daya manusia harus dilakukan secara profesional oleh sekolah tersebut. Mengelola sumber daya manusia di era globalisasi bukan merupakan hal yang mudah, oleh sebab itu berbagai macam cara dilakukan seperti musyawarah guru mata pelajaran, workshop, seminar pendidikan dan lain sebagainya.

Urgensi dan signifikasi fungsi dan peranan pemimpin sekolah didasarkan pada pemahaman bahwa keberhasilan sekolah merupakan keberhasilan kepala sekolah. Oleh sebab itu kepala sekolah perlu memiliki kompetensi yang disyaratkan, agar dapat merealisasikan visi dan misi yang diemban lembaganya. Dalam pradigma baru manajemen pendidikan, kepala sekolah minimal mampu berfungsi sebagai edukator, manager, administrator, supervisor, leader, inovator dan motivator.

Kepala sekolah harus mampu mengambil keputusan yang cepat dan tepat, memberikan petunjuk dan pengawasan, meningkatkan kemauan dan kemampuan tenaga pendidik, membuka komunikasi dua arah dan mendelegasikan tugas.

Kepala sekolah sebagai pemimpin harus memiliki karakter khusus yang mencakup kepribadian, keahlian dasar, pengalaman dan pengetahuan profesional serta pengetahuan administrasi dan pengawasan.

Menurut pendapat Robbins (2006: 432), fungsi kepemimpinan sebagai tugas manajer, mencakup tugas motivasi karyawan, mengarahkan orang lain memilih saluran komunikasi yang efektif, serta memecahkan konflik-konflik. Fungsi kepemimpinan dapat juga dikatakan sebagai proses memepengaruhi kebiasaan-kebiasaan orang lain guna mencapai tujuan organisasi, yang meliputi komunikasi tentang tugas pekerjaan kepada para karyawan dan juga metode-metode untuk menyelesaikan tugas-tugas tersebut.

Dalam proses dinamika kepemimpinan untuk usaha mempengaruhi aktivitas individu demi tercapainya suatu tujuan didalam suatu situasi tertentu, maka diperlukan gaya kepemimpinan. Keating (2010:11) mengidentifikasi dua gaya kepemimpinan yaitu gaya dengan orientasi tugas (task oriented) dan gaya dengan orientasi manusia (human relation oriented).

Hal ini menggambarkan bahwa iklim sekolah sebagai keadaan atau kondisi dalam satu rangkaian yang secara langsung atau tidak langsung, sadar atau tidak sadar, dapat mempengaruhi kerja guru. Iklim kerja disekolah yang kondusif sangat dibutuhkan oleh seorang guru untuk menumbuhkan dorongan dalam diri guru tersebut untuk bekerja lebih bersemangat. Ini berarti bahwa iklim kerja sekolah berpengaruh terhadap tinggi rendahnya motivasi kerja para guru.

Motivasi kerja guru adalah daya dorong yang berpengaruh, membangkitkan, mengarahkan dan memelihara perilaku seorang guru untuk melakukan tugasnya sebagai pendidik dan pengajar dengan segala kemampuan dan keahliannya guna mewujudkan tujuan pendidikan yang telah ditentukan.

Dari pandangan tersebut diatas menunjukkan bahwa kemampuan profesional guru dalam kegiatan pembelajaran, perlu didukung oleh komitmen yang tinggi, gaya kepemimpinan yang baik, iklim kerja yang kondusif serta motivasi kerja yang positif, sehingga optimalisasi curahan waktu dan pemikiran untuk mendidik siswa berjalan dengan baik dan secara tidak langsung turut menentukan tinggi rendahnya prestasi kinerja guru.

Berdasarkan fenomena diatas, dengan mengidentifikasi faktor-faktor yang mempengaruhi kinerja guru, ada sisi menarik untuk dikaji dan dicermati sejalan dengan komitmen pemerintah secara normatif untuk meningkatkan mutu pendidikan dengan meningkatan kinerja guru, serta tuntutan para steakholder terhadap kinerja guru yang semakin tinggi.

Melalui uraian tersebut diatas, maka diadakan penelitian "Kontribusi Gaya Kepemimpinan Kepala Sekolah, Komitmen Organisasi, Iklim Kerja dan Motivasi Kerja Guru Terhadap Kinerja Guru di SMP Negeri 2 Singaraja".

\section{METODOLOGI}

Subjek penelitian ini adalah seluruh guru SMP Negeri 2 Singaraja, yang berjumlah 60 orang. Teknik pengambilan sampel yang dikenakan sebagai subjek penelitian 
menggunakan teknik populasi studi atau sampling jenuh. Hal ini dilakukan mengingat populasi yang cukup kecil, sehingga memungkinkan untuk meneliti semua populasi (Agung, 2014: 69). Penelitian ini menggunakan rancangan expost facto. Penelitian ini menggunakan dua jenis variabel, yaitu empat variabel bebas yaitu adalah gaya kepemimpinan kepala sekolah $\left(X_{1}\right)$, Komitmen Organisasional $\left(X_{2}\right)$, Iklim kerja $\left(X_{3}\right)$, Motivasi Kerja $\left(X_{4}\right)$ serta satu variabel terikat yaitu kinerja guru $(\mathrm{Y})$. Selanjutnya, data penelitain dikumpulkan dengan kuesioner dan dokumentasi serta dianalisis dengan analisis regresi berganda.

\section{HASIL DAN PEMBAHASAN}

Hasil penelitian tentang kontribusi gaya kepemimpinan kepala sekolah di SMP Negeri 2 Singaraja menunjukkan bahwa kontribusi gaya kepemimpinan kepala sekolah berada pada kategori sangat baik, dimana rata-rata skor mencapai 138.567, berada pada rentang $\overline{\mathrm{X}} \geq 139,995$. Dengan analisis ditemukan hubungan yang signifikan antara gaya kepemimpinana kepala sekolah terhadap kinerja guru SMP Negeri 2 Singaraja dengan persamaan regresi $\hat{y}=16,328+0,622 X_{1}$, dengan $F_{\text {reg }}=223,281$ bahwa semakin baik persepsi guru tentang gaya kepemimpinana kepala sekolah maka semakin meningkat kinerja guru, demikian sebaliknya apabila gaya kepemimpinana kepala sekolah kurang efektif maka kinerja guru akan menurun. Dengan koefisien korelasi 0,891, kontribusi sebesar $30,91 \%$ dan sumbangan efektif (SE) sebesar 25,43\% ditemukan hubungan serta pengaruh yang sangat kuat antara kontribusi gaya kepemimpianan kepala sekolah terhadap kinerja guru di SMP Negeri 2 Singaraja.

Atau dengan kata lain kinerja guru yang baik pada SMP Negeri 2 Singaraja lebih banyak dipengaruhi oleh gaya kepemimpinan kepala sekolah. Untuk meningkatkan kinerja guru secara optimal, maka kepala sekolah harus mampu menciptakan sekolah yang efektif dalam memenuhi harapan pelanggan dan mampu menciptakan motivasi kerja guru yang tinggi.

Dari penelitian ini didukung juga oleh hasil penelitian yang dilakukan sebelumnya oleh Kadek Trisna Wedari (2016) dengan penelitian berjudul "Kontribusi Gaya Kepemimpinan Kepala Sekolah, Motivasi Kerja dan Iklim Kerja terhadap Kinerja Guru SMKN 2 Seririt". Penelitian ini merupakan penelitian ex-post facto, karena gejala yang diselidiki secara wajar dan tidak dimanipulasi, dengan populasi sampel berjumlah 53 orang guru, yang menggunakan analisis regresi ganda yang dilanjutkan dengan analisis determinasi. Hasilnya (1) kecenderungan gaya kepemimpinan kepala sekolah SMKN 2 Seririt berada pada rata-rata 126,75, sehingga termasuk dalam kategori sangat baik. Hasil analisis juga menunjukkan bahwa adanya kontribusi yang signifikan kepemimpinan kepala sekolah terhadap kinerja guru SMKN 2 Seririt, dengan sumbangan efektif sebesar 13,38\%. (2) kecenderungan motivasi kerja SMKN 2 Seririt berada pada rata-rata sebesar 119,25, hasil analisis ini menunjukkan kontribusi yang signifikan motivasi kerja terhadap kinerja guru dengan sumbangan efektif $29,03 \%$. (3) variabel iklim kerja SMKN 2 Seririt berada pada ratarata sebesar 204,17 dan sumbangan efektif sebesar 30,24\% hasil ini menunjukkan adanya kontribusi yang signifikan terhadap kinerja guru. (4) kontribusi yang signifikan gaya kepemimpinan kepala sekolah, iklim kerja dan motivasi kerja secara bersama-sama terhadap kinerja guru dengan kontribusi sebesar $72,7 \%$.

Sesuai dengan apa yang dikemukakan oleh Wahjusumidjo (2002: 83) Kepala Sekolah merupakan pimpinan dalam suatu organisasi atau lembaga. Sedangkan sekolah adalah sebuah lembaga dimana menjadi tempat menerima dan memberi pendidikan. Dengan menggunakan gaya kepemimpinan yang tepat, kepala sekolah sebagai seorang tenaga fungsional guru yang diberi tugas untuk memimpin suatu sekolah dapat mencapai tujuan dari pendidikan nasional.

Berdasarkan pemaparan diatas, dapat disimpulkan bahwa gaya kepemimpinan kepala sekolah sangat mempengaruhi kinerja bawahannya terutama guru-guru. Dengan kata lain bahwa gaya kepemimpinan kepala sekolah memberikan kontribusi yang signifikan terhadap kinerja guru. 
Selanjutnya, hasil pengujian hipotesis kedua, menunjukkan bahwa terdapat kontribusi yang signifikan komitmen organisasi terhadap kinerja guru di SMP Negeri 2 Singaraja. Kontribusi komitmen organisasi berada pada kategori sangat baik, dimana ratarata mencapai 132.033 , skor berada pada rentangan $\bar{X} \geq 120$. Artinya terdapat hubungan yang signifikan antara komitmen organisasi dengan kinerja guru di SMP Negeri 2 Singaraja. Komitmen secara umum dapat diartikan ssebagai keterikatan pegawai pada organisasi dimana pegawai tersebut bekerja. Persamaan garis regresi $\hat{y}=24,744+0,514 \mathrm{X}_{2}$ dengan $\mathrm{F}_{\text {reg }}$ $=107.211$, kontribusi sebesar $24,31 \%$ menandakan bahwa persepsi guru tentang komitmen organisasi memberikan hubungan yang signifikan terhadap kinerja guru di SMP Negeri 2 Singaraja. Semakin tinggi persepsi guru akan komitmen organisasi maka semakin meningkat juga kinerja guru, demikian pula sebaliknya jika komitmen organisasi rendah akan berakibat menurunnya kinerja guru. Dalam penelitian ini ditemukan juga hubungan antara kontribusi komitmen organisasi terhadap kinerja guru dengan koefisien korelasi 0,061 dan sumbangan efektif $20,02 \%$, yang menunjukkan bahwa pengaruh komitmen organisasi cukup tinggi terhadap kinerja guru.

Komitmen dibutuhkan oleh organisasi agar sumber daya manusia kompeten dalam organisasi, dapat terjaga dan terpelihara dengan baik. Hal itu tidak hanya membawa dampak pada keuntungan organisasi sekolah secara umum, tetapi jiga akan berdampak pada perkembangan kemampuan dan efektivitas kerja guru itu sendiri. Nilai-nilai yang ditanamkan pimpinan akan mampu meningkatkan kemauan, kesetiaan dan kebanggaan serta lebih jauh menciptakan efektifitas kerja. Hal ini cenderung terjadi karena komitmen kerja guru yang meliputi ketiga dimensi yang disebutkan diparagraf sebelumnya memberikan kontribusi yang signifikan terhadap kinerja guru di SMP Negeri 2 Singaraja.

Penelitian ini sejalan dengan hasil penelitian yang dilakukan oleh I Dewa Ketut Sunardia, (2015) dengan judul "Kontribusi Supervisi Akademik, Iklim Kerja Sekolah, dan Motivasi Kerja terhadap Kinerja Guru pada SD Gugus I Mengwi Kabupaten Badung". Penelitian ini adalah penelitian ex-post facto dengan populasi seluruh guru sebanyak 65 orang, teknik pengambilan sampel menggunakan proportional random sampling. Metode analisis yang digunakan adalah dengan metode regresi sederhana, regresi ganda dan korelasi parsial. Hasil penelitian menunjukkan bahwa (1) terdapat kontribusi supervisi akademik terhadap kinerja guru pada SD Gugus I Mengwi Kabupaten Badung dengan kontribusi sebesar 31,5\%, (2) terdapat kontribusi iklim kerja sekolah terhadap kinerja guru pada SD Gugus I Mengwi Kabupaten Badung dengan kontribusi sebesar 32,2\%, (3) terdapat kontribusi motivasi kerja terhadap kinerja guru pada SD Gugus I Mengwi Kabupaten Badung dengan kontribusi sebesar 46,0\% dan (4) terdapat kontribusi supervise akademik, iklim kerja sekolah, motivasi kerja secara bersama-sama terhadap kinerja guru pada SD Gugus I Mengwi Kabupaten Badung.

Kemudian, hasil penelitian ketiga tentang iklim kerja di SMP Negeri 2 Singaraja, menunjukkan bahwa iklim kerja berada dikategori baik, dimana rata-rata skor mencapai 206.267 berada pada $\bar{X} \geq 199,995$ dengan persamaan regresi $\hat{y}=25,190+0,343 X_{3}$ dan $F_{\text {reg }}$ 65,897 , kontribusi sebesar $25,40 \%$. Hal ini berarti bahwa iklim kerja memberikan hubungan yang signifikan terhadap kinerja guru di SMP Negeri 2 Singaraja. Semakin baik atas pandangan guru tentang iklim kerja maka semakin meningkat kinerja guru, dan sebaliknya jika iklim kerja buruk akan mengakibatkan kinerja guru menurun. Dalam hubungan kontribusi iklim kerja terhadap kinerja guru di SMP Negeri 2 Singaraja terdapat hubungan sebesar 0.532 dan sumbangan efektifnya sebsar $20,87 \%$, menunjukkan bahwa pengaruh yang tinggi antara iklim kerja terhadap kinerja guru.

Yang mendukung hasil penelitian ini, dilakukan sebelumnya oleh Luh Tutik Suardani (2017), dengan judul "Kontribusi Kepemimpianan Kepala Sekolah, Komitmen Organisasi, dan Iklim Kerja terhadap Kinerja Guru SMP Negeri di Kecamatan Mengwi". Penelitian ini tergolong penelitian ex-post facto, dengan jumlah populasi sampel 97 orang guru, analisis data yang digunakan yaitu regresi sederhana maupun ganda, yang dilanjutkan dengan analisis determinasi. Dari hasil analisis ditemukan (1) terdapat hubungan yang signifikan kepemimpinan kepala sekolah dengan kinerja guru SMP Negeri di Kecamatan Mengwi dengan kontribusi $25,3 \%$ dan sumbangan efektif sebsear $8,08 \%$, (2) terdapat hubungan 
yang signifikan komitmen organisasi dengan kinerja guru SMP Negeri di Kecamatan Mengwi denagn kontribusi sebesar 30,6\% dan sumbangan efektif sebesar 15,26\%, (3) terdapat hubungan yang signifikan iklim kerja dengan kinerja guru SMP Negeri di Kecamatan Mengwi dengan kontribusi sebesar $48,1 \%$ dan sumbangan efektif sebesar $34,97 \%$ dan (4) terdapat hubungan yang signifikan secara bersama-sama kepemimpinan kepala sekolah, komitmen organisasi dan iklim kerja dengan kinerja guru SMP Negeri di Kecamatan Mengwi dengan kontribusi sebsesar 58,31\%.

Iklim kerja merupakan suatu kondisi atau keadaan suasana kerja lembaga yang dirasa nyaman, tenang dan bebas dalam melakukan pekerjaan tanpa ada rasa terpaksa maupun tidak tertekan, dan suasana yang harmonis ditengah-tengah perbedaan yang ada pada guru, siswa dan masyarakat.

Iklim kerja merupakan suasana ditempat dimana seseorang itu berada, yang memberi kesan kepada semua anggota, bahwa mereka dianggap setara. Suasana lingkungan sekolah yang nyaman dan asri dapat memberikan dampak pada keadaan para guru, siswa dan masyarakat serta situasi sekolah aman tentram.

Guru yang mempunyai iklim kerja yang tinggi dan tidak hanya untuk mengutamakan kepentingan sendiri, akan dapat melakukan tugas dengan tepat sesuai profesinya sebagai guru. Sehingga iklim kerja berkontribusi secara signifikan terhadap kinerja guru di SMP Negeri 2 Singaraja.

Keempat, hasil penelitian yang mengkaji kontribusi motivasi kerja di SMP Negeri 2 Singaraja menunjukkan bahwa kontribusi motivasi kerja pada kategori sangat baik, dimana rata-rata skor mencapai 122,50 dan skor ini berada pada rentangan $\overline{\mathrm{X}} \geq 120$. Hasil analisis menemukan bahwa terdapat hubungan yang signifikan antara motivasi kerja terhadap kinerja guru di SMP Negeri 2 Singaraja, dengan persamaan garis regresi $\hat{y}=25,190+$ $0,343 \mathrm{X}_{4}$ dan $\mathrm{F}_{\text {reg }}=65,897$. Ini menandakan motivasi kerja memberikan kontribusi yang signifikan terhadap kinerja guru karena semakin tinggi motivasi kerja guru di SMP Negeri 2 Singaraja maka dapat meningkatkan kinerja guru, sebaliknya jika motivasi kerja kurang efektif maka mengakibatan kinerja guru menurun. Kontribusi motivasi kerja memberikan hubungan sebesar 19,40\% terhadap kinerja guru, koefisien korelasi sebesar 0,346 dengan sumbangan efektifnya sebesar $15,97 \%$, ini menunjukkan pengaruh yang kuat antara motivasi kerja terhadap kinerja guru.

Penelitian ini sejalan dengan penelitian yang dilakukan oleh I Nyoman Sukadana (2015), yang berjudul "Kontribusi Gaya Kepemimpinan, Motivasi Kerja Guru dan Supervisi Akademik Kepala Sekolah terhadap Kinerja Guru di Gugus IV Kecamatan Kuta Kabupaten Badung". Dalam penelitiannya dinyatakan bahwa (1) terdapat kontribusi yang signifikan terhadap gaya kepemimpinan kepala sekolah terhadap kinerja guru dalam menjalankan tugas pembelajaran di Sekolah Dasar Gugus IV Kecamatan Kuta Kabupaten Badung tahun pelajaran 2013/2014 dengan kontribusi sebesar 35,5\%, sumbangan efektifnya sebesar $36,9 \%$

Berdasarkan hasil temuan tersebut dapat disimpulkan bahwa terdapat determinasi yang positif dan signifikan antara kemampuan manajerial kepala sekolah, motivasi kerja guru dan ikim kerja terhadap kepuasan kerja guru SMP Negeri di Kecamatan Kuta secara terpisah maupun simultan. Dengan demikian ketiga faktor tersebut dapat dijadikan prediktor tingkat kecenderungan kepuasan kerja SMP Negeri di Kecamatan Kuta, Kabupaten Badung.

Motivasi merupakan salah satu faktor yang penting dan menentukan dalam proses manajemen pendidikan. Keberhasilan organisasi pendidikan dalam mencapai suatu tujuan sebagian besar bergantung pada kemampuan pimpinan untuk bekerja. Oleh karena itu, kepala sekolah atau pimpinan organisasi harus memiliki motivasi tinggi dalam melaksanakan tugasnya.

Motivasi adalah keinginan dan kemauan seseorang untuk mencurahkan segala upayanya dalam mencapai tujuan. Oleh sebab itu tidak ada motivasi apabila tidak dirasakan adanya suatu keinginan atau kebutuhan. Kebutuhan-kebutuhan tersebut merupakan rangsangan atau dorongan timbulnya motivasi untuk melakukan tindakan-tindakan tertentu.

Seorang guru apabila memiliki motivasi kerja yang tinggi, tentunya selalu bertugas dan menyelesaikan tanggungjawabnya dengan semangat. Semangat tersebut akan mampu 
membuat hasil kerja dari guru menjadi lebih maksimal. Sehingga dapat disimpulkan bahwa motivasi kerja memberikan kontribusi yang signifikan terhadap kinerja guru di SMP Negeri 2 Singaraja.

Selanjutnya, hasil penelitian kelima menunjukkan bahwa terdapat kontribusi yang signifikan Gaya Kepemimpinan Kepala Sekolah, Komitmen Organisasi, Iklim Kerja dan Motivasi Kerja terhadap Kinerja Guru di SMP 2 Singaraja dengan persamaan garis regresi $\hat{y}$ $=18,053+0,622 X_{1}+0,514 X_{2}+0,343 X_{3}+0,442 X_{4}$, Freg $=64,076(\rho<0,05)$ yang berarti signifikan dan linier.

Kinerja/prestasi kerja merupakan hasil kerja yang dicapai seseorang dalam melaksanakan tugas-tugas yang dibebankan kepadanya yang didasarkan atas kecakapan, pengalaman dan kesungguhan serta tepat waktu. Wujud kinerja dapat dilihat dri tingkat prestasi kerja yang berupa hasil kerja, kemampuan dan penerimaan atas kejelasan delegasi tugas serta minat seorang pekerja.

Kinerja guru disekolah tentunya dipengaruhi oleh berbagai macam faktor seperti gaya kepemimpinan kepala sekolah, komitmen organisasi, iklim kerja dan motivasi kerja. Keempat faktor tersebut merupakan faktor yang berasal dari dalam dan luar diri seorang guru.

Gaya kepemimpinan mengandung pengertian sebagai suatu perwujudan tingkah laku dari seorang pemimpin, yang menyangkut kemampuannya dalam memimpin. Perwujudan tersebut biasanya membentuk suatu pola atau bentuk tertentu. Baik buruk proses pendidikan disuatu sekolah banyak ditentukan oleh gaya kepemimpinan kepala sekolah, sebab kepala sekolah adalah orang yang paling bertanggungjawab atas segala sesuatunya yang sudah, sedang dan yang akan terjadi disekolah tersebut. Untuk itu bagaimana pola dan metode yang diterapkan kepala sekolah melalui gaya kepemimpinannya akan mempengaruhi para guru dalam mengajar dan mempengaruhi murid untuk belajar.

Selain gaya kepemimpinan kepala sekolah, komitmen organisasi sepertinya menjadi satu sikap yang ditonjolkan dalam penelitian ini, yaitu mencakup tiga dimensi secara emosional, merasakan, kebutuhan dan keinginan, biaya, percaya dan loyalitas menurut pendapat teori para pakar dalam penelitian ini diduga pula memilki keterkaitan terhadap kinerja guru.

Kekutan keempat variabel bebas dengan kinerja guru secara berurutan adalah, gaya kepemimpinan kepala sekolah, komitmen organisasi, iklim kerja dan motivasi kerja. Dengan demikian dapat disimpulkan bahwa sebelum dan setelah diadakan penelitian, ada hubungan yang signifikan antara gaya kepemimpnan kepala sekolah, komitmen organisasi, iklim kerja dan motivasi kerja secara bersama-sama maupun secara terpisah. Variabel gaya kepemimpinan kepala sekolah, komitmen organisasi, iklim kerja dan motivasi kerja yang tinggi di SMP Negeri 2 Singaraja dapat dijadikan prediktor kecenderungan pencapaian dan peningkatan kinerja guru.

\section{PENUTUP}

berikut.

Berdasarkan penelitian yang telah dilakukan dapat disimpulkan hal-hal sebagai

1. Kecenderungan gaya kepemimpianan kepala sekolah di SMP Negeri 2 Singaraja berada pada rata-rata 138,57 sehingga termasuk dalam kategori sangaat baik. Hasil analisis menunjukkan bahwa adanya kontribusi yang signifikan gaya kepemimpinan kepala sekolah terhadap kinerja guru di SMP Negeri 2 Singaraja dengan sumbangan efektif sebesar $25,43 \%$.

2. Kecenderungan komitmen organisasi di SMP Negeri 2 Singaraja berada pada rata-rata 132,03 sehingga termasuk dalam kategori sangaat baik. Hasil analisis menunjukkan bahwa adanya kontribusi yang signifikan komitmen organisasi terhadap kinerja guru di SMP Negeri 2 Singaraja dengan sumbangan efektif sebesar 20,02\%.

3. Kecenderungan iklim kerja di SMP Negeri 2 Singaraja berada pada rata-rata 206,27 sehingga termasuk dalam kategori sangaat baik. Hasil analisis menunjukkan bahwa 
adanya kontribusi yang signifikan iklim kerja terhadap kinerja guru di SMP Negeri 2 Singaraja dengan sumbangan efektif sebesar $20,87 \%$.

4. Kecenderungan motivasi kerja di SMP Negeri 2 Singaraja berada pada rata-rata 122,50 sehingga termasuk dalam kategori sangaat baik. Hasil analisis menunjukkan bahwa adanya kontribusi yang signifikan motivasi kerja terhadap kinerja guru di SMP Negeri 2 Singaraja dengan sumbangan efektif sebesar $15,97 \%$

5. Hasil penelitian ini menunjukkan kontribusi gaya kepemimpianan kepala sekolah, komitmen organisasi, iklim kerja dan motivasi kerja secara bersama-sama terhadap kinerja guru di SMP Negeri 2 Singaraja dengan kontribusi sebesar 82,29\%.

Berdasarkan simpulan yang didapatkan dari penelitian yang telah dilakukan, dapat disarankan hal-hal sebagai berikut.

1. Kepada guru, agar selalu meningkatkan komitmen organisasi, iklim kerja dan motivasi kerja sehingga kinerja guru dapat ditingkatkan secara maksimal, karena penelitian ini sudah terbukti memeberikan kontribusi yang signifikan terhadap kinerja guru.

2. Kepada kepala sekolah, agar selalu meingkatkan kemampuan kepemimpinan pelayananyang dimilkinya dan selalu menjaga komitmen organisasi sehingga sekolah benar-benar maju dalam dunia pendidikan, karena keempat variabel memberikan kontribusi yang signifikan terhadap kinerja guru.

3. Kepada peneliti lain, disarankan untuk mengembangkan penelitian ini, sehingga permasalahan yang terjadi didunia pendidikan dapat diminimalkan.

\section{DAFTAR PUSTAKA}

Agung, Anak Agung Gede. 2014. Metodologi Penelitian Pendidikan. Malang: Aditya Media Publishing.

Agung, Anak Agung Gede. 2015.Statistika Dasar untuk Pendidikan.Yogyakarta: Depublish

Colquitt, Lepine and Wesson. 2009. Organizational Behavior, Improving Performance and Commitment in the Workplace. Boston McGrow-Hill. International Edition

Candiasa, I Made. 2010. Statistik Multivariat Disertai Aplikasi SPSS. Singaraja. Undiksha Press.

Cushway, Barry \& Derek Lodge. 2000. Organizational Behavior And Design. Jakarta: Elex Media Computindo

Dantes, Nyoman. 2012. Metode Penelitian. Yogyakarta. Hadi

Fattah. Nanang. 2004. Konsep Manajemen Berbasis Sekolah (MBS) dan Dewan Sekolah. Bandung: Pustaka Bani Quraisy.

Gibson James.L., 1987. Organisasi Perilaku, Struktu, Proses. Jakarta: Penerbit Erlangga.

Daryanto, H.M.2010. Administrasi Pendidikan. Jakarta. Rineka Cipta.

Hamzah, B.U.2007. Pengembangan Instrumen untuk Penelitian. Jakarta. Dilemma Press. Jakarta.

Hadi, Sutrisno. 1991. Analisa Butir Instrumen. Yogyakarta. Andi Offset

Hermino. Agustinus. 2014. Kepemimpinan Pendidikan di Era Globalisasi. Yogyakarta: Pustaka Pelajar.

Husaini. Usman. 2006. Mananjemen Teori Praktek dan Riset Pendidikan. Jakarta. Bumi Aksara. 
Koyan. Wayan. 2012. Statistik Pendidikan "Teknik Analisis data Kuantitatif". Singaraja: Universitas Pendidikan Ganesha Press

Karwati, Euis. dan Priansa, Donni Juni. 2013. Kinerja dan Profesionalisme Kepala Sekolah: Membangun Sekolah yang Bermutu. Bandung: Alfabeta.

Luthans. Fred. 1995. Organizational Behavior. Mc Graw Hill Internasional. New York

Luthans. 2008. Perilaku Organisasi. Yogyakarta : Andi

Mulyadi. 2010. Kepemimpinan Kepala Sekolah Dalam Mengembangkan Budaya Mutu. Malang: UIN Maliki Press.

Mulyasa, E. 2003. Manajemen Berbasis Sekolah. Bandung. PT. Remaja Rosda Karya.

Mulyasa. E. 2013. Manajemen dan Kepemimpinan Kepala Sekolah. Jakarta: PT. Bumi Aksara

Samani. Muchlas. 2006. Mengenal Sertifikasi Guru di Indonesia. Surabaya: SIC dan Asosiasi Peneliti Pendidikan Indonesia

Susanto. Ahmad. 2016. Konsep Strategi dan Implementasi Manajemen Peningkatan Kinerja Guru. Jakarta. Prenada Media Group.

Sudjana. 2001. Metode Statistika. Bandung: Tarsito.

Sugiyono. 2006. Statistika untuk Penelitian. Bandung: Alfabeta

Sunardia, I Dewa Ketut. 2015.Kontribusi Supervisi Akademik, Iklim Kerja Sekolah Dan Motivasi Kerja terhadap Kinerja Guru pada SD Gugus I Mengwi Kabupaten Badung. Tesis. Undiksha Singaraja.

Suharsa Putra. Unar. 2016. Kepemimpinan Inovasi Pendidikan (mengembangkan spirit Enterpreneurship menuju Learning School). Bandung : PT. Refika Aditama

Sukadana, I Nyoman. 2015. Kontribusi Gaya Kepemimpinan, Motivasi Kerja Guru dan Supervisi Akademik Kepala Sekolah terhadap Kinerja Guru di Gugus IV Kecamatan Kuta Kabupaten Badung. Tesis. Undiksha Singaraja.

Suardani, Luh Tutik. 2017. Kontribusi Kepemimpinan Kepala Sekolah, Komitmen Organisasi dan Iklim Kerja terhadap Kinerja Guru SMP Negeri di Kecamatan Mengwi. Tesis. Undiksha Singaraja.

Toha, Miftah. 2005. Kepemimpinan dalam Manajemen. Jakarta: Raja Grafindo Persada.

Undang-Undang RI Nomor 20 Tahun 2003. Tentang Sistem Pendidikan Nasional. Jakarta: Depdiknas.

Usman, Nasir. (2012). Manajemen Peningkatan Mutu Kinerja Guru. Bandung: Citapustaka Media Perintis.

Wahjosumidjo. 2005. Kepemimpinan Kepala sekolah. Jakarta: PT Raja Grapindo Persada 
Wahyudi. 2012. Kepemimpian Kepala Sekolah dalam Organisasi Pembelajaran. Bandung: Alfabeta.

Wedari, Kadek Trisna. 2016. Kontribusi Kepemimpinan Kepala Sekolah, Motivasi Kerja dan Iklim Kerja terhadap Kinerja Guru SMKN 2 Seririt. Tesis. Undiksha Singaraja 